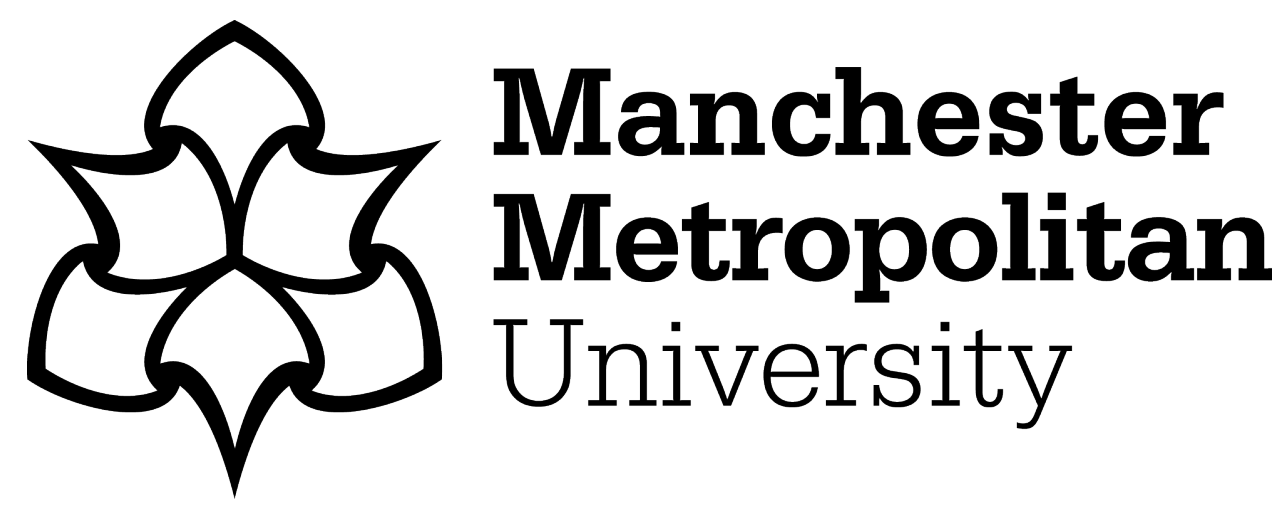

Di Feliciantonio, C and Aalbers, MB (2017) The Prehistories of Neoliberal Housing Policies in Italy and Spain and Their Reification in Times of Crisis. Housing Policy Debate, 28 (1). pp. 135-151. ISSN 1051-1482

Downloaded from: https://e-space.mmu.ac.uk/624252/

Version: Accepted Version

Publisher: Taylor \& Francis

DOI: https://doi.org/10.1080/10511482.2016.1276468

Please cite the published version 
Di Feliciantonio, C. and Aalbers, M.B. (2017) The pre-histories of neoliberal housing policies in Italy and Spain and their reification in times of crisis. Housing Policy Debate 27: in press. DOI: 10.1080/10511482.2016.1276468

\title{
The Pre-Histories of Neoliberal Housing Policies in Italy and Spain and their Reification in Times of Crisis
}

\author{
Cesare Di Feliciantonio \& Manuel B. Aalbers
}

\begin{abstract}
In this paper we analyze the historical roots of neoliberal housing policies, mottos and principles in Italy and Spain, two countries with a Mediterranean welfare regime, showing how they are embedded in the twentieth century fascist-dictatorial regimes of Mussolini and Franco. To stimulate economic growth in a situation of autarchy, both regimes saw the construction sector and the promotion of homeownership as keys to fuel the accumulation process while believing this guaranteed social order. After acknowledging these longstanding roots, we show how the current phase of neoliberalism, characterized by severe austerity policies, relies on similar principles, the main reforms approved in both countries proceeding mainly towards cuts to service provisions and resources, while the promotion of homeownership remains unchallenged.
\end{abstract}

Keywords: neoliberalism; housing policy; austerity policies; Mediterranean welfare regime; Italy; Spain 


\section{Introduction}

When considering the impact of the current crisis across the so-called PIIGS countries (Portugal, Italy, Ireland, Greece and Spain), the housing situation appears to be dramatic: falling housing prices and mortgage loan availability on the one hand and a massive increase in evictions, foreclosures and vacant properties on the other (e.g. Charnock, Purcell, \& Ribera-Fumaz, 2014; Kitchin, O'Callaghan, Boyle, Gleeson, \& Keaveney 2012; Waldron, 2016). This crisis flows from a period characterized by the affirmation of neoliberal housing policies, their logics being reinforced in the current phase of austerity politics (e.g. Aalbers, 2013b; Di Feliciantonio, 2016b; Peck, 2012). When considering their transnational dimension, neoliberal housing policies appear to be unavoidable and inescapable: homeownership is prompted as the key towards a so-called assetbased welfare policy (in fact, an asset-based wealth policy) through the expansion of credit, while public welfare provision is strongly reduced with new contractual forms of public-private partnerships (and ownership of assets) emerging and a consequent increase in indebtedness for the consumer-citizen (e.g. Aalbers, 2015; Raco, 2013; Rolnik, 2013; Ronald, 2008).

Centered on Italy and Spain, this paper shows how these neoliberal housing policies have deep historical roots in twentieth century fascist-dictatorial regimes. One of the key-principles of neoliberal housing, i.e. "the construction of a homeowners' society", was strongly promoted in Italy under Mussolini and in Spain under Franco, contributing to the formation of the so-called "Mediterranean" welfare regime in relation to housing, characterized by high homeownership rates and the weak, or only temporary, provision of social housing (Castles \& Ferrera, 1996; Allen, Barlow, Leal, Maloutas, \& Padovani, 2004). Although homeownership historically also has been promoted by liberal governments, for example in Great Britain in the interwar period (e.g. Ball, 1983), the fascist regimes of Italy and Spain determined the shift towards homeowners' societies with the state not committed to providing social housing permanently but favoring homeownership in different ways. The fact that other regimes have also promoted homeowners' societies does not diminish the relevance of the fascist regimes for the trajectory of both housing and welfare in Italy and Spain.

By tracing the roots of neoliberal housing policies in Italy and Spain in the fascist regimes of the twentieth century, we support those conceptualizations of neoliberalism as a diversified process that is able to make value and subsume specific histories and place-based characteristics and peculiarities, its character being always "exceptional" (Brenner, Peck \& Theodore, 2010; Larner, 2000; Ong, 2006). We therefore see the logic driving neoliberal policies "not as a standardized universal apparatus, but a migratory technology of governing that interacts with situated sets of elements and circumstances" (Ong, 2007: 5). It follows that our use of the term "pre-histories" of neoliberal housing policies aims at showing how neoliberal rationalities in Italy and Spain are built on principles originated far before the progressive affirmation of neoliberalism at the global scale from the 1980s onwards. We are not arguing that neoliberalism is necessarily embedded in fascism, but rather that neoliberal housing policies in Italy and Spain are embedded in their respective fascist pasts and that there are similarities in the pre-histories of neoliberalism in these two countries.

The term "pre-histories" also indicates that we are not talking about the implementation of neoliberalism proper, but of earlier policies, in this instance fascist policies, that have contributed to shape the exceptional trajectories of neoliberalism in Southern Europe. In this sense, we are not discussing how neoliberalism has developed in Italy and Spain but how fascism lay some of the groundwork on which later post-fascist and neoliberal policies have built. Holland and Scholar, 
building on the work of Cave (1999), suggest "pre-histories" as a critical method: whereas many historians have focused on the "afterlives" of historical events, i.e. post-fascism in our case, the idea of "pre-histories" focuses on a contextualization of developments, not in order to fix the meaning of a specific object in time, but "to trace the shifting dialogue between the object and its various contexts through time" (Holland \& Scholar, 2009: 2). Homeowners' societies are not unique to the neoliberal era, but already developed under fascist regimes in twentieth century Southern Europe. By tracing the roots of the 'homeowners' society' in Italy and Spain under their fascist past, we are not arguing that neoliberal policies are identical to those implemented under Mussolini's and Franco's regimes; our aim is to show how these regimes have reshaped housing policies so deeply that even contemporary housing policies still rely on the same principles.

Although associating neoliberalism with fascist regimes and their protectionist policies may appear contradictory at a first glance, the paper builds on those studies that have demonstrated how the affirmation of neoliberalism has often relied on non-democratic political practices and violence (e.g. Klein, 2007; Ong, 2006, 2007; Springer, 2012). In this respect, it is important to note how for both countries several studies have acknowledged the legacy of the fascist past in the neoliberal present. For Italy, the housing literature has stressed the persistence of strong protectionism in the mortgages market and the overall banking system (e.g. Aalbers, 2007; Baldini, 2010; Baldini \& Poggio, 2014). For Spain, recent studies in the English-language literature have stressed the embeddedness of the contemporary housing model in Franco's regime (e.g. García-Lamarca \& Kaika, 2016; Gonick, 2015b; Hoekstra \& Vakili-Zad, 2011; Palomera, 2014; Vives \& Rullan, 2014). Since no such argument has been posited for Italian housing policies, we have turned to historical studies in Italian from the 1970s, notably the works of Bortolotti $(1971 a ; 1971 b ; 1978)$ about the policies of fascism in relation to the construction sector and the rentier class. The comparison of these two countries allows us to show how the configuration of welfare systems is the result of complex historical, socio-political and economic processes, rejecting any idea about homeownership being somehow intrinsic to Southern European culture. This assumes a particular relevance in the current historical phase characterized by the progressive affirmation of "assetbased welfare" in Western countries and beyond (Doling \& Ronald, 2010a; 2010b). The histories of housing policies in Mediterranean countries have the potential to inform what is occurring around the globe with indebted homeownership and personal responsibilization having become main dispositifs of neoliberalism.

After acknowledging the long-standing roots of neoliberal housing policies and the principles on which they are based, we show how the current phase of neoliberalism, characterized by severe austerity policies, reifies the same rationality, the main reforms approved in both countries proceeding mainly towards cuts to service provisions and resources. Indeed, as shown for other pillars of the welfare regime, notably health and pensions (e.g. Léon, Pavolini, \& Guillén, 2015; Pavolini \& Reitano, 2015), housing policies implemented in times of austerity mark a continuum with those implemented in the years of the boom. Although it is true that fascist regimes tended to be highly interventionist, we should not forget that state intervention under neoliberalism is also severe (Aalbers, 2013a; Panitch \& Konings, 2009) because actually existing neoliberalism is "a self-contradictory form of regulation-in-denial" (Peck 2010, xiii).

Emphasizing the embeddedness of neoliberal housing policies reified in current times of austerity politics in the fascist past of Italy and Spain is not aimed at erasing or underestimating the legacy of the years following the end of the regimes. Our aim is to show how the neoliberal project, with respect to housing, was not imported from "elsewhere" (Ong, 2007) but deeply embedded in national histories and power relations. The paper contributes to a better understanding of the 
ability of neoliberalism to subsume specific political and socio-economic projects and relations originally conceived with a different political and economic scope. While the promotion of the "homeowners' society" in both Italy and Spain originally served as a way to stimulate growth in a context of autarchy and favor the formation of specific subjectivities, in the neoliberal present it has occurred in a context of market liberalization (especially in Spain), although still with the precise economic and political function to drive the accumulation process (Charnock, Purcell, \& RiberaFumaz, 2014; Lopez \& Rodriguez, 2011) and forge new subjectivities (Di Feliciantonio, 2016a, 2016b; Gonick, 2015b). Beyond the political and ideological project, this paper acknowledges the economic rationality behind the promotion of homeownership. In order to stimulate growth through housing and real estate, the state intervened massively in the economy subsidizing developers (in both countries) as well as agencies promoting affordable housing for middle classes, pushing tenants to buy their houses (in Italy).

By emphasizing how housing policies implemented in times of austerity deepen the process of neoliberalization of the welfare systems of the two countries, the paper contributes to the debate on the (post-)crisis reshaping of the Southern European welfare regime, exemplified by three recently published special issues (e.g. Guillén \& Petmesidou, 2014; Guillén \& Pavolini, 2015; Pavolini \& Reitano, 2015b). These special issues, however, center primarily on health, pensions, care and reforms in labor markets, while almost completely ignoring "the wobbly pillar of the welfare state" (Torgersen, 1987), that is, housing. This underrepresentation can be read as a sign of the traditional weakness of the housing sector within Southern European welfare systems (e.g. Castles \& Ferrera, 1996; Ferrera, 1996). We believe housing deserves special attention for at least two reasons. First, housing has been a main driver of economic growth for the two countries during the recent decades of neoliberalization. Second, housing exemplifies the contradiction between use value as a basic need and exchange value as a store of value (e.g. Pattillo, 2013), leading to the emergence of strong social mobilization around housing in recent years, like the Plataforma de los Afectados por la Hipoteca (PAH) in Spain (e.g. Di Feliciantonio, 2016a; García-Lamarca, 2016; Gonick, 2015a) and different squatting initiatives in Italy (e.g. Di Feliciantonio, 2016b).

The paper is structured as follows. In section 2 we discuss the recent debate on the embeddedness of neoliberalism and the specific role of the state, focusing mostly on the housing sector. Acknowledging the tight connections between housing policies and the configuration of the welfare regime, section 3 presents the main characteristics of the Southern European welfare regime, highlighting the main policies implemented in the housing sector mostly aimed at promoting homeownership. In section 4 we trace the origins of these policies in the fascist regimes of Mussolini in Italy and Franco in Spain. Section 5 analyses the reification of the same rationality behind these policies in the current phase of austerity or "permanent strain" (Pavolini, Léon, Guillén, \& Ascoli, 2015). Finally, in the conclusion we emphasize the need for more diachronic and comparative studies.

\section{The embeddedness of neoliberal housing policies}

There are many ways to define neoliberalism and there are many histories of neoliberalism. Although neoliberalism means different things to different people and places, it is possible to define a number of key characteristics of neoliberalism, its history being complex and non-linear (Audier, 2008; 2012). Contemporary neoliberalism (hereafter: neoliberalism), defined by Chabal (2012) as a "curios assemblage", is a specific movement within capitalism that relies on some but not all of the 
old principles of economic liberalism (Aalbers, 2013a). Indeed neoliberalism "is a prescriptive concept that articulates a normative vision of the proper relationship between the state, capital, property, and individuals" (Ganti, 2014: 93) as well as "a class project, masked by a lot of neoliberal rhetoric about individual freedom, liberty, responsibility, privatization and the free market" (Harvey, 2009: 1). In this process, different arms of the state are not silent actors but rather active ones. Despite all talk of markets, state intervention under "actually existing neoliberalism" (Brenner \& Theodore, 2002) is very different from the discourse (or ideology) of neoliberalism, and state intervention under neoliberalism has actually been severe (Aalbers, 2013a; Panitch \& Konings, 2009).

Audier (2008; 2012), Mirowski \& Plehwe (2009), Birch \& Mykhnenko (2010), Peck (2010), Jones (2012) and Aalbers (2017), among others, have written on the roots of neoliberalism. Neoliberalism had to be actively constructed in each national context and it did so, at least in part, through existing and older institutions, practices and ideas. Not all of these ideas come from "elsewhere" (Ong, 2007); some of them were nationally or locally produced and are reproduced-and thereby possibly altered-under neoliberalism. If we accept the argument that neoliberalization is a project of socio-spatial transformation (Peck, Theodore \& Brenner, 2010), it follows that neoliberal governmentalities can travel through different contexts and scales (Ong, 2007) as well as that they need to be embedded in existing contextualized institutions, whether those are found at the national scale or elsewhere. In other words, a relational understanding takes serious the claim that neoliberalism does not come out of a single control center and is constituted across scales (Aalbers, 2017; England \& Ward, 2007; Peck, Theodore, \& Brenner, 2010). This has led several scholars to conceptualize neoliberalism as an assemblage involving multiple projects, different actors and political repertoires (e.g. Li, 2007; Ong, 2006, 2007). In fact, "most of the political work of neoliberalism involves practices of de- and re-articulation of existing elements into new configurations, assemblages or constellations" (Newman, 2014: 3293).

In housing markets, policies that promote privatization, as well as commodification more widely speaking, are typically seen as indicative of neoliberalism. Policies and practices that enable larger and riskier mortgage loans do not so much support homeownership as they support increasing house prices and the financialization of housing (Aalbers, 2008). What is known in the policy and academic literature as "asset-based welfare" (Regan \& Paxton, 2001) is a very thinly disguised neoliberal and financialized discourse that is mobilized to break down welfare and replace it by housing wealth. Instead, it should be labeled "asset-based wealth". Where social housing is allowed to subsist, it is either subject to stigmatization and marginalization or its management is commodified and rents are raised. Homeownership, on the other hand, is discursively supported almost everywhere and fiscally supported in many countries. The ideology of homeownership is constructed through supporting ideologies of wealth accumulation and markets (Kemeny, 1981; Ronald \& Elsinga, 2012).

The expansion of homeownership has made those people or places at one time considered too poor or too different (e.g. in terms of race/ethnicity) to be profitable, become profitable "emerging markets" (Listokin \& Wyly, 2000). Yet, as these groups and places are not simply included into homeownership, but typically locked into expensive mortgage loans on which they may default, this creates even more opportunities to profit. Defaulting on a loan can be made easy and expensive (e.g. through teaser rates or balloon payments). Then, if people are unable to pay off their debt, a "new set of emerging markets" can be exploited: one in housing speculation (buying up foreclosed properties), a second in the buy-to-rent (private rented) market, and a third in citizenship, which a range of countries, including Spain and the US, offer for investment in real 
estate. While for most Western countries the affirmation of such a model has been linked to the rise of neoliberalism between the end of the 1970s and the 1980s, with public housing stock privatized and tenants pushed to buy (e.g. Hodkinson, Watt \& Mooney, 2013), Southern European countries have followed a different path, as we will show in the next section.

\section{Housing policies in the Southern European welfare regime}

Several studies have stressed the tight relation between housing policies and the configuration of welfare regimes (e.g. Allen et al., 2004; Pareja Eastway \& San Martín Varo, 1999; 2002), especially in those countries with very high rates of homeownership, including those in Southern Europe. A vast literature from the 1990s (e.g. Castles, 1994; Castles \& Ferrera, 1996; Ferrera, 1996; Leibfried, 1992; Mingione, 1995; Rhodes, 1996) has traced the main characteristics of the South European welfare model: the "mixed" model of public intervention with universal provision in the domain of health and a fragmented pension system linked to the specific employment sector; the low intervention to support people at risk of poverty through income redistribution; a strong particularism in the provision of services, usually associated to political clientelism; and, more important, the strong level of (private) familism, thus access to welfare benefits often relies on family networks.

When considering the role of housing in the configuration of Southern European welfare regimes, the main characteristic is the weak intervention of the state in the provision of social and affordable housing and/or direct support to tenants (e.g. Terranova, 2011). To give an indication, in Italy the share of households paying a rent below the market value in 2008 was around $4 \%$, while in Spain, before the recent campaigns of the $\mathrm{PAH}$ (see section 5), it was just above 2\%; in France and the UK the numbers were, respectively, $16 \%$ and $18 \%$ (data cited in Baldini, 2010: 84). Moreover, the inadequacy of rent subsidies is revealed by the share of households spending more than $30 \%$ of their disposable income on rent, after subsidies: $24 \%$ in Italy and $30 \%$ in Spain, but only $12 \%$ in France and $8 \%$ in the UK (source: EU-SILC/Eurostat). In fact, public resources for social housing have traditionally been very limited in both countries, with informal/abusive housing through selfconstruction developing as the most widespread response, especially in so-called "Mediterranean cities" (e.g. Berdini, 2010; Leontidou, 1990). In Italy, the stock has received little investment in the last three decades and is aimed at satisfying only the needs of poor households (Indovina, 2005); in 2009 a mere $0.1 \%$ of GDP was spent on housing benefits (source: Eurostat). In the case of Spain, social housing policies have mainly consisted of subsidizing owner-occupied dwellings sold at below-market prices to low-income households (e.g. Hoekstra, Heras, \& Etxezarreta, 2010).

With the weak provision of housing through the welfare state, homeownership has been favored through different policy instruments. In Italy, fiscal treatment of homeownership is rather favorable: "Until the early 1980s, owning real estate properties in Italy was basically tax free" (Ave, 1996: 77); imputed rents are taxed on the basis of administrative values, which are below real market values; tax rebates do exist for mortgage interests; and intergenerational transfer are taxed in a favorable way (sometimes almost tax free). Furthermore, In Italy, we find "a co-evolution of the institutions of family and home ownership, by which the first enables the second, and the second increases the importance of the first" (Aalbers, 2007: 183). The family is an important source for the down payment, for monthly payments, and also for inheritance: family transfers help overcome liquidity constraints in housing purchases by shortening saving time by one to two years and allowing households to purchase considerably larger homes (Del Boca \& Lusardi 2003; Guiso \& Jappelli 2002). This way, the intergenerational transmission of homeownership in Italy appears pivotal to the reproduction of a family-based welfare regime both in the allocation of financial resources and 
care provision: around $35 \%$ of homeowners aged over 50 in Italy and $28 \%$ in Spain accessed property through transfers from the family, while this is the case for only $15 \%$ in France and around $3 \%$ in the Netherlands (Poggio, 2008). As a result, homeownership is extremely difficult to access (or keep) for people coming from lower-class families, middle-class families experiencing financial restraint, or for those who decide to migrate towards the main metropolitan areas of the country where prices are higher.

In Spain, fiscal policies traditionally also have favored homeownership. Before 1991 national policies did not include the aim to support homeownership for low-income groups. The national fiscal policies towards homeownership emerged as a deeply regressive policy instrument favoring upper classes purchasing multiple houses by giving them a considerable tax reduction. After 1991, tax relief has been centered on the income tax bill (for a detailed analysis of tax reliefs in Spain, see Pareja Eastaway \& San Martín Varo, 1999). Beyond fiscal policies, the Spanish state has favored access to homeownership through a complete liberalization of the mortgage market since the early 1990s (Royal Decree 1932/91). Combined with increasing liquidity in global financial markets, changes in planning regulation and an increasing demand for real estate from the tourism sector (e.g. Coq-Huelva, 2013; García, 2010), this liberalization led to a massive boom in the building sector, the main driver of the Spanish growth model (Lopez \& Rodriguez, 2011), and a related increase in new mortgages issued, the main effect being the homeownership rate rising to $87.1 \%$ in 2007 (source: EMF, 2009). ${ }^{1}$ After the burst of the bubble in 2008, housing prices have collapsed, foreclosures and evictions have risen dramatically, and the number of unsold and vacant units has increased (e.g. Colau \& Alemany, 2012; 2013; García, 2010).

In both countries, the promotion of homeownership through subsidies has made renting less attractive despite the presence of protective measures for tenants (e.g. Del Boca \& Lusardi, 2003; Hoekstra \& Vakili-Zad, 2011; Pareja Eastaway \& Sanchez Martínez, 2011; Pareja Eastaway \& San Martín Varo, 2002). The decrease in the rental sector has made the overall market less flexible, while demand for housing itself has become more flexible (Tosi \& Cremaschi, 2001). Several rounds of liberalization were implemented in the 1970s and the 1980s: in Italy the 1978 reform was meant to limit rent increases but resulted in tenant evictions on the one hand and to underinvestment on the other hand; in Spain the 1985 reform fully liberalized the rental market, tenants lost protections and the majority of new leases were short-term.

\section{The pre-histories of neoliberal housing policies in Italy and Spain under fascist regimes}

So far, we have argued that the high homeownership rates characterizing Southern European welfare regimes result from specific state policies that have made renting less attractive. Our aim in this section is to show how the rationalities driving the support to homeownership have longstanding roots, notably in twentieth century fascist-dictatorial regimes. While a growing number of studies in geography and urban studies have stressed these origins for Spain (e.g. GarcíaLamarca \& Kaika, 2016; Gonick, 2015b; Hoekstra \& Vakili-Zad, 2011; Vives \& Rullan, 2014), in Italy such studies were primarily undertaken by historians in the 1970s (e.g. Bortolotti, 1971a; 1971b; 1978), while urban scholars have mostly focused on the legacy of fascist planning (e.g. Berdini, 2010). We will first analyze the Italian case, stressing the tight connection between housing policies and urban planning, and subsequently present the model developed under Franco's regime in Spain. As a counterfactual we will also compare the rise of the homeowners' society under fascist regimes to the development in a liberal regime, i.e. Great Britain. 
4.1 Italy: creating a homeowners' society through mortgages (for the few) and informal housing (for the many)

To have a full idea of the housing doctrine of the fascist regime, and its tight connections to urban planning, we first have to consider the social situation of the country after World War I: there was a severe scarcity of houses and the living conditions of most of the population were extremely poor, so masses of people responded by occupying land in the countryside as well as abandoned and vacant buildings in urban areas (Bortolotti, 1971a; 1978). Because of such a tense situation, the government was forced to extend the freezing of rent prices proclaimed during the war until 1920, while trying to favor new buildings destined to low-income groups through tax incentives. In 1919 and 1920 we also saw the creation of several tenants' associations linked to the socialist party, which pushed for the control of rents and addressed violent campaigns against the rentier class, including occupations of properties. These protests involved mainly the working classes, who were the most affected by the post-war difficult situation. In Rome, for example, data from the 1921 Census show that more than 170,000 people lived in a condition of overcrowding (cited in Ficacci, 2014).

In terms of property tenure, data from the 1921 Census show that the 'liberal revolution' initiated by Giolitti before the war had very limited effects in terms of access to homeownership for lowermiddle classes. In fact, according to the Census data only $1.9 \%$ of households owned a property of any type, down from $2.1 \%$ in $1911,2.5 \%$ in 1901 and $2.8 \%$ in 1881 . $^{2}$ These data support the claims of several historians: the Giolitti "liberal revolution" was mostly aimed at supporting the interests of both the rising Italian industrial bourgeoisie and the traditional rentier class (e.g. Carocci, 1961; De Felice, 1969). Although at the beginning of the twentieth century homeownership was still very limited across several countries in Western Europe, the Italian rate was much lower than, for instance, the British one (10\% in 1914; cited in Ball, 1983).

Once the fascists came to power in October 1922, they immediately gained the support of the rentier class as a way to repress socialist and communist dissent from lower classes, including tenants (Bortolotti, 1971a; 1971b; 1978). In July 1923 their support was rewarded with the elimination of any form of rent caps (Bortolotti, 1971a). Nevertheless, the regime kept an ambivalent position towards the traditional rentier class during the next two decades. Fascist-run media openly supported tenants against the parasitism and speculation of landlords (Bortolotti, 1971a; 1971b). Furthermore, as a response to the difficult economic situation, decreases of rent prices were enforced by law (Castronovo, 1972; Chabod, 1961), although this was accompanied by a strong decrease in property taxes. ${ }^{3}$ According to Bortolotti (1971a; 1971b; 1978), we can interpret this as the main manifestation of the change within the rentier class occurring during fascism. A new class of developers/builders/rentiers combining all the different components of real estate and finance substituted the traditional rentier class. Indeed, the main fiscal exemptions introduced by the regime concerned new buildings and demolitions, with a new law approved in 1928 guaranteeing a 25 -year full tax exemption for new buildings realized within a specific term.

The fascist period was one of a massive expansion of real estate and the financial activities related to it, enabled by the liberalization of the construction sector, which was seen as the driving sector of the economy under the regime's state of autarchy. Building activities increased constantly, even in the years of the global recession, reaching its peak in 1936 with 890,000 new residential units (Bortolotti, 1971a). Moreover, real estate holding companies increased strongly (there were 140 in 
$1913,2,325$ in 1927 and 3,002 in 1929), while land credit registered a massive boom (+85\% between 1927 and 1929; +60\% between 1929 and 1932) and so did mortgages for urban properties (+190\% between 1927 and 1932) (ibid). In this expansion of real estate and finance, the condominium played a central role: barely developed when the fascists got the power, condominiums soon became the main evidence of the building activity of the country, accounting for $76 \%$ of new construction in 1930 and $85 \%$ in 1933 (source: ibid). The new politics centered on the condominium for the emerging middle classes (mainly public employees and a limited portion of the working classes) relied on a key assumption: tenants had to become homeowners in order to maximize capital investments. The main results of this process are visible in the 1931 "Special Enquiry on Housing" realized together with the population census: in ten years the share of homeowners increased to $16.8 \%$ in cities with a population over 100,$000 ; 29.1 \%$ in cities with a population between 50,000 and 100,000 residents; and $39.2 \%$ in cities with a population between 20,000 and 50,000 residents. $^{4}$

So it is under the fascist regime that Italy started its path towards a homeowners' society, a process that in some other countries was favored by liberal regimes. For Great Britain, Ball (1983) has explored how homeownership in the years between the two world wars became the most socially accepted and valued tenure. The homeownership rate increased from 10\% in 1914 to $32 \%$ in 1938. However, there are at least two crucial differences between the homeownership booms in Italy and Great Britain. Firstly, while in Italy the construction sector worked as a driver of economic growth in a situation of autarchy; in Great Britain the rising of homeownership was linked to the configuration of class relations after WWI, with mass unemployment in former industrial regions and new industries in the Midlands and the South East (Ball, 1983: 30). Secondly, in the same years of the homeownership boom, Great Britain registered the emergence of affordable housing stock owned by local authorities (10\% in 1938), opening the way to what became one of the main pillars of the British welfare system after WWII (ibid). The Italian fascist regime, on the other hand, saw affordable public housing mainly as the premise for middle classes to buy (e.g. Bortolotti, 1971a, 1978, Castronovo, 1975; Villani, 2012), a vision that is still present, as we will see in section 5. In Italy, "super-popular" houses, characterized by very poor material and living conditions, were built at the extreme edges of the main cities (e.g. Samona', 1973) to transfer lower classes displaced by the city centers under the logics of "disembowelments" (sventramenti) through which primarily lower-class housing was demolished and its residents displaced. These disembowelments were aimed at reshaping the visual perspective of the historical centers, emphasizing the presence of monuments (Villani, 2012: 207-208)).

Disembowelments were strongly contested by traditional rentiers while they aimed at benefiting the new developer/rentier class through delineating new areas, often at the peripheries of cities, to relocate poor households. However, this effort from the administration was not sufficient to respond to the increasing housing demand due to the massive migrations from the countryside, notably in the South, towards the main cities. So the response of the administration was one of tolerance towards self-constructed, informal and abusive settlements without a legal entitlement in order to guarantee access to housing. As a result, a stable tenure remained limited to public employees and white-collar workers, while lower-income groups were excluded from legal entitlements to property and the socio-legal stability they can create.

The new orientation of the regime was strongly supported by an ideological apparatus aimed at creating a stable society of homeowners. While Mussolini defined property as "the result of work, the son of saving" in 1932 (source: Bortolotti, 1971a), other main exponents of the fascist regime 
were engaged in this ideological project. Bernado Attilio Genco, the secretary of the Fascist Federation of Owners, for example, praised

\begin{abstract}
the considerable advantage for national and social order given by the diffusion of real estate property. (...) The propaganda for the fractionation of real estate property and the own house (...) can give a remarkable contribution to the resolution of the housing crisis, involving towards these buildings great amount of small but continuous savings. (Genco, 1929: 89, authors' translation)
\end{abstract}

As highlighted by several urban planners and historians (e.g. Berdini, 2008, 2010, Villani, 2012), the legacy of fascist housing policies and planning orientation has continued throughout the entire twentieth century (and it is still alive, as we argue in section 5), as highlighted by three main characteristics of Italian housing policies: first, homeownership has been strongly promoted by the main political party that emerged after WWII, the Christian Democrats, its promotion not opposed by communist and socialist oppositions (e.g. Bottini, 2000; Magagnoli, 2012); second, public provision of social housing has remained marginal even in the years of the economic boom, with the persisting divergence between units destined to middle classes as a premise to buy them, and low-quality units for poorest groups (e.g. Baldini, 2010; Magagnoli, 2012); third, tolerance for informal and abusive units without legal entitlement in areas not destined to housing in city masterplans (e.g. Berdini, 2010).

\title{
4.2 Spain: building a homeowners' society to guarantee stability
}

In Spain, awareness about the historical roots of the "homeowners' society" project concerns both academia and the general public, in part thanks to the effort undertaken by the Plataforma de los Afectados por la Hipoteca ( $\mathrm{PAH}$, see section 5) to de-stabilize the dominant narrative about homeownership being somehow a "natural" characteristic of the country (Colau \& Alemany, 2012; 2013). Therefore, the afterlife of housing policies introduced by Franco's regime in those implemented under democratic governments has been acknowledged in the Spanish debate.

According to Palomera (2014: 221), "the housing policies of the last 50 years have turned the property market into the only way to have a roof over one's head for most of the population." As a result, $54 \%$ of the Spanish population was renting a house in the 1950, just $12 \%$ did in 2005 and 22\% did so in 2013 (EMF, 2015; Pareja Eastway \& San Martín Varo, 2002). The two main instruments used by the state to favor homeownership were to make renting unattractive and to privatize social housing (Palomera, 2014), although it should be noted that social rented housing never amounted to more than 3\% in Spain. Concerning the former, the 1946 Urban Rent Law fixed the indefinite extension of leases together with the freezing of prices, impacting negatively on new investments in the rental sector. This orientation was confirmed by the 1964 Urban Rent Law, which imposed permanent limits for the upgrading of rent agreements.

Policies implemented since the 1960s mostly aimed at subsidizing homeownership (66\% of the new units of the 1961-76 Housing Plan approved by the Franco regime). Lopez and Rodriguez (2011) have defined this form of intervention of the Spanish state as "Thatcherism avant la lettre": state-subsidized units progressively entered the private market. The state directly subsidized the developers, financing up to $60 \%$ of the total value of new developments, people accessing 
homeownership through the Spanish Mortgage Bank, Banco Hipotecario de España (Leal, 2005; Lopez \& Rodriguez, 2011).

As under Italian fascism, homeownership as the key of Franco's housing policy was seen as a way to drive capital accumulation (Llorden Miñambres, 2003). In fact, "Franco's dictatorship, established in 1939, saw the provision of state-subsidized housing as a means to enhance national stability and secure support for the regime, while promoting economic development" (GarcíaLamarca \& Kaika, 2016: 5). The ideological project supporting the economic function of housing against the stagnation of the national economy is manifested in the 1957 speech by José Luis Arrese, the first Housing Secretary, who stated: "We want a country of homeowners, not proletarians" (cited in García-Lamarca \& Kaika, 2016: 5). His words echo Genco's words for the Italian fascist regime reported in the previous sub-section, homeownership seen as a main vehicle to maintain public order. According to Colau \& Alemany (2012), the homeownership project had a double function for Franco's regime: avoiding sources of conflict between the State and specific social sectors (e.g. tenants, rentiers, people in social housing)—the same conflict we have seen at work in Italy when Mussolini got the power-as well as establishing a mechanism of social control,

converting insubordinate spirits into more disciplined, moral individuals. (...) Whoever owned property also had something to lose, concrete interests to defend and little time left for conspiring. (ibid: 38 )

Indeed, this is what the contemporary neoliberal critique would interpret as the internalization of neoliberal subjectivities. In a recent paper, Gonick (2015b) has emphasized how such a mixed state intervention, made up of direct subsidies to developers and liberalization of markets to promote economic growth in a situation of autarchy, relied on the individual responsibilization of the new homeowner: "the young family man must seize the opportunities to improve his own lot in life instead on relying on outside forces" (p. 6). So we see how one of the main principles founding neoliberal rationality, i.e. personal responsibilization (e.g. Rose, 1999), is the result of the policies implemented during the fascist regime of Franco.

So the foundation of a "homeowners' society" under Franco's regime echoes the political project and measures implemented under Italian fascism, the welfare systems of the countries thus acquiring a similar configuration. Although such a configuration has remained largely uncontested in the transition to democracy in both countries, the next section will focus on the current phase of austerity politics to show how the same principles are still at work today.

\section{The reification of neoliberal housing policies in times of austerity}

Although the dimension and the violence of the global financial crisis have affected Italy and Spain to a different extent, the underlying tendency in relation to housing is the same: increasing levels of indebtedness, impoverishment, evictions and foreclosures (e.g. Cano Fuentes, Etxezarreta, Dol, \& Hoekstra, 2013; Di Feliciantonio, 2016a, 2016b). In Italy, the number of evictions approved by the courts has increased from 33,768 in 2005 to 56,269 in 2010 and 69,250 in 2014 (source: Italian Ministry of Internal Affairs). ${ }^{5}$ In Spain, between 2008 and 2014 570,000 homes were foreclosed, while 250,000 households are estimated to have been evicted between 2008 and 2014 (data in García-Lamarca \& Kaika, 2016: 10). 
The aim of this section is to show how the policies implemented in both countries have not been able to reverse the trend because they are still based on the same principles that have been driving housing policies for many decades. Although surely many things have changed since the fall of both fascist regimes, many of the tenets of the fascist housing regime have been furthered in the years before the global financial crisis and are not being challenged in contemporary housing policies. Despite the following analysis being mostly centered on policies implemented by national governments, they should be related to the severe austerity discipline imposed by EU institutions. In fact, indebtedness has become the main dispositif of contemporary neoliberalism, leading those indebted (including states) to prioritize the repayment of debt over any other social or political intervention (e.g. Lazzarato, 2015).

The response to the crisis by the Italian and the Spanish governments has been twofold. In a first phase (2008-2010), they tried to undertake anti-cyclical measures in order to stimulate the economy, while after 2011 they have mostly engaged in severe austerity measures aimed at respecting the EU parameters on deficit and debt (e.g. Léon et al., 2015; Pavolini \& Reitano, 2015a). In Italy the different governments that came to power since 2011 have approved deep reforms of the welfare system (e.g. in the labor market and education), using the rhetoric of "the need to do instead of discussing", thus mainly depriving the parliament of its main, legislative function (e.g. Pavolini \& Reitano, 2015a; Del Pino \& Pavolini, 2015). It is worth noting how most of the welfare reforms and cuts approved by the governments actually involve sectors which had undergone a strong decentralization in the years preceding the crisis (Del Pino \& Pavolini, 2015), as a result of which municipalities and regions are required to manage the provision of welfare services with fewer resources, and without the possibility to use new taxation instruments.

Spanish governments have proceeded in a similar fashion: the immediate response to the crisis included increased public expenditure for welfare provision, notably for the unemployed, as well as the bailout of several savings banks (Léon et al., 2015). Most of the recapitalized banks are regional savings banks controlled by the main political parties that had become key actors in the twin boom of construction and mortgage loans characterizing the country after 1991. However, the triumph of the Popular Party (PP) at the national elections of 2011 marked a decisive turning point: austerity soon became the mission of the new government led by Mariano Rajoy, approving severe cuts while reforming important sectors, such as the labor market. The results of the labor reforms approved in Spain (and elsewhere in Southern Europe) have been defined by Ferrera (2012) as "subtractive recalibration", i.e. the long-standing inequalities between the insiders and the outsiders in the labor job market have started to decrease not because the outsiders gained access to more rights and services but because the rights of the insiders were reduced, creating a situation of losers without winners. Moreover, like in Italy, most of the cuts to social services have concerned domains under the control of regional and municipal governments that are thus forced to execute and manage the consequences of the decisions taken by national governments (Léon et al., 2015; Del Pino \& Pavolini, 2015).

The literature on welfare in Southern Europe (e.g. Ascoli \& Pavolini, 2015; Ferrera, 2012; Guillén \& Pavolini, 2015; Léon et al., 2015; Pavolini \& Reitano, 2015a) has stressed how the reforms implemented in the current phase of "permanent strain" (Pavolini et al., 2015) do not mark a rupture with the rationality behind neoliberal policies implemented in the last decades, but a rapid acceleration and intensification of them. However, such comparative analyses do not consider the role of housing policies in the configuration of the welfare system, thus reifying the historical lack of attention devoted to housing in Southern European welfare regimes. 
For Italy, we can consider the Housing Plan (Piano Casa) approved by the Renzi government in 2014 as the hallmark of the reification of the rationality that has dominated since fascism. The first article of the Housing Plan increases the resources to the national funds to support tenants in the private rental sector and "innocent" (incolpevoli) defaulting tenants. The fund to support tenants in private rent was instituted in 1998, but has experienced a progressive dismantling of resources: from $€ 335.7$ million in 2001 to $€ 9.9$ million in 2011 and completely zeroed under the Monti government in 2012. Through the new Housing Plan the fund has received $€ 100$ million per year in 2014 and 2015. The fund for "innocent" defaulting tenants, instituted under the Letta government in 2013, has received trifling amounts: originally budgeted for $€ 20$ million per year, it has been raised to $€ 35.7$ million in 2014 and $€ 32.7$ million in 2015 .

Beyond these limited resources, Article 9 of the Housing Plan introduced a more advantageous tax regime for landlords in all the large cities and main provincial towns: the cedolare secca ${ }^{6}$ is lowered to $10 \%$. The (very limited) support to private rent is counterbalanced by Article 3 , which aims at accelerating the "dismissal" (i.e. the selling) of social housing units and the properties of municipalities and other local institutions though a special subsidy to help people currently living in social housing units to become homeowners. This is further reinforced by Article 8 which gives tenants of new social housing units realized through the Housing Plan the right to buy after a mere seven years. In other words, social housing is depicted as a temporary solution for those who currently cannot afford to buy a house (Deriu, 2014), a vision rooted in Mussolini's regime.

Finally, Article 5 of the Housing Plan introduces a punitive measure against squatters: they will no longer have the right to install water and electricity facilities without providing a legal entitlement to the property. In a country with a long-standing tradition of squatting and informal housing ( $\mathrm{Di}$ Feliciantonio, 2016b), this appears as a sanction following the technocratic logic of neoliberalism (e.g. Peck \& Tickell, 2002). It appears even more punitive if we consider that it also excludes squatters from the right to demand social housing for five years. People in need are thus deprived of the right to protest and self-organize.

Despite the violence of the crisis leading to a massive boom of evictions and repossessions, the response of the Spanish government has been quite slow and unwilling or unable to really stop them, while it was much faster in bailing out and nationalizing savings banks. The first measure was introduced in 2009 through the Institute of Official Credit (Instituto de Crédito Oficial, ICO, a public bank), allowing the temporary reduction of mortgage repayments (up to 50\%) for those unemployed households with a mortgage of less than $€ 170,000$ (Cano \& Etxezarreta, 2014). The delayed repayments were repackaged into new loans to be paid off in 15 years, starting from 2012. This scheme was unsuccessful because the criteria to access it were too restrictive and because banks could opt in but many did not (Cano Fuentes et al., 2013).

In 2012, a new law was approved (nr. 6/2012) that contained a code of "good practice" opening the possibility to restructure debts and eventually get to the dación en pago (the recourse of the mortgage loan). However, the parameters to enter this program were very restrictive: all the members of the household should be unemployed, the household should not have any savings, the mortgage repayment should be more than $60 \%$ of the disposable income, and the price of the dwelling should be below respectively $€ 120,000$ (small municipalities) or $€ 200,000$ (main metropolitan areas). The most controversial clause of this law requires the impossibility to repay the debt also for anyone guaranteeing the mortgage (Cano \& Etxezarreta, 2014; Cano Fuentes et al., 2013). This way, the law was unable to respond to one of the most impelling problems related to the housing crisis, i.e. people losing their houses because they had signed as guarantors for 
their relatives. So the co-evolution of family and homeownership underwent a punitive turn: you have to pay or lose your house, even if one of your relatives is defaulting.

At the end of 2012 another law was approved (nr. 27/2012) in order to stop evictions (but not the foreclosing process or the mortgage repayment) for the most vulnerable households. Again the parameters were highly restrictive in terms of household composition (e.g. families with very young children or people with a handicap) and income levels (household income under $€ 19,200$ ). To respond to the pressure of the Plataforma de los Afectados por la Hipoteca (PAH) and its campaign for a new law on mortgages, the government approved a new law (nr. 1/2013), motivated by the increasing wave of evictions and foreclosures around the country. Yet, the main requests of the $\mathrm{PAH}$ and other social movements did not materialize in the new law: only evictions of the most vulnerable households were stopped. Despite the inadequacy of the government to go beyond very limited emergency solutions, the housing market has been reshaped by the crisis very rapidly, with the homeownership falling to $77.7 \%$ in 2013 (Eurostat data). However, foreclosed and evicted households have been able to find a solution thanks to the engagement of the PAH with local institutions and owning financial institutions, pressing them to accord rents at reduced prices (alquileres sociales) or for free (Di Feliciantonio, 2016a). According to Eurostat data, tenants renting at a reduced price or for free have increased from $7.8 \%$ in 2011 to $9.1 \%$ in 2013.

\section{Conclusions}

The afterlives of fascism are widely discussed in Italy and Spain, but the other side of the coin, the pre-histories of neoliberalism in twentieth century fascist regimes, has so far received little attention, in particular in the field of housing. In this paper we have argued that neoliberalism is not necessarily embedded in fascism, but that the neoliberal regimes of Italy and Spain built on several foundations laid during their respective fascist periods. In order to promote economic growth in a situation of autarchy, the regimes of Mussolini in Italy and Franco in Spain saw the construction sector and the promotion of homeownership as keys to fuel the accumulation process while believing this guaranteed social order. In this respect, both regimes created extremely favorable incentives for developers (zero taxation in Italy, direct subsidies in Spain), while promoting access to mortgages for lower or middle classes in order to build homeowners' societies. While a number of studies have recently engaged with this kind of historical perspective for Spain, we turned to earlier studies on the fascist past in Italy in order to enable a relational comparison.

The pre-histories of neoliberal housing policies continue their influence in the present times of "permanent strain" (Pavolini et al., 2015). By expanding the perspective developed by recent studies around welfare in Southern Europe, we have demonstrated how housing policies adopted to cope with the impelling housing problems of hundreds of thousands of people in both countries rely on the same rationality originated under fascist regimes. The promotion of homeownership and the recourse to financial instruments continue to shape the political agendas of Italy and Spain. However, these policies have proved to be inadequate to address the housing needs for increasing numbers of people. In Spain, rates of repossessions and evictions are still extremely high (see, for example, Colau \& Alemany, 2013), while in Italy they have increased progressively after 2008 (Bazzoli, 2015).

The main counter-tendencies to these policies implemented by official governments emerge from the part of social movements that have been able to produce both autonomous and 
institutionalized solutions to re-affirm the right to (decent) housing. This has occurred especially in Spain, where the PAH developed a diversified series of practices and claims to improve the housing conditions of tens of thousands of people (Di Feliciantonio, 2016a, Gonick, 2015a). On the one hand, they have physically blocked thousands of evictions and when evictions could not be stopped they have promoted the occupation of vacant buildings owned by financial institutions. On the other hand, they have engaged in prolonged negotiations with political and financial institutions to promote legal ways to guarantee the right to housing. The main result of this strategy is the increasing number of tenants paying a reduced rent or no rent at all. In Italy, squatting has reemerged as a collective political practice to give a shelter to thousands of people, mostly those who cannot afford anymore to pay rent (Di Feliciantonio, 2016b), although the response of institutions has been repressive. These initiatives pose a challenge to the future of neoliberal housing policies and the configuration of the welfare regimes, fighting for the de-commodification of housing and challenging the power of banks supported by the state.

Policies to promote homeownership-increasingly in the form of financialized homeownershipdeveloped differently in Italy and Spain than in other countries. Long before homeownership became the "normalized form of tenure" in a country like the UK, the ideological and political preference for homeownership had already taken hold in Southern Europe. Although the fascist past in both countries was of course not linearly continued in Italy and Spain, several of the tenets of the Mussolini and Franco regimes were never seriously challenged, including the preferential treatment of homeownership and the financial institutions enabling this form of housing tenure. Comparisons with Greece and Portugal could teach us more about housing under fascism in Southern Europe, but comparisons with Germany would also be fruitful to understand why postwar housing ideology and practices developed so differently there.

If we want to understand contemporary neoliberalisms, we need to understand how they built on and borrow from principles and policies developed in earlier periods. Since neoliberalism has not developed from one single control central, the only way to understand the development of national and sub-national neoliberalisms, is to focus on the pre-histories specific to a countries, region or city, preferably in comparative perspective, as we have begun to do in this paper. Contrary to countries like the UK, France, the Netherlands or Sweden, Southern European countries, including not just Italy and Spain but also Greece and Portugal, never developed or promoted any substantial alternative forms of housing tenure. Even when they appeared to do so, social housing was either meant as a temporary solution, a first step into homeownership, or it was developed in the peripheries of the cities in a far more marginalized environment than their counterparts in Northwestern Europe. Not only did social housing remain a very marginal tenure, Italy and Spain also did not rely on systems of rent support and housing benefits that supported, and continue to support, many people in Northwestern Europe, including the German speaking countries were homeownership rates remain comparatively low.

Although we see many "common trajectories" in the development of housing markets in different European and North American countries (Fernandez \& Aalbers, 2016), for example in the ideological and political treatment of homeownership, and in particular of financialized homeownership, we also see how the different housing pre-histories live on in contemporary housing institutions. In another way, the Southern European labor market regime with a great deal of casualized labor is increasingly becoming normalized in Northwestern Europe and North America. Paradoxically, while financialized homeownership is increasingly the only option for most households, the labor market system on which it relies-the security of labor, income and workplace-is progressively becoming an exception in more and more countries (Aalbers, 2015). 
More comparative and diachronic studies are needed, not only to understand how on the one hand national pre-histories and on the other common trajectories give shape to unique, national housing regimes, but also to re-assess the political and historical roots of neoliberal policies in order to challenge their presumed 'naturalness' and unavoidability.

\section{Acknowledgements}

The authors would like to thank the reviewers and (guest) editors for constructive feedback. The work of Manuel B. Aalbers was generously supported by European Research Council grant 313376.

\section{References}

Aalbers, M.B. (2007). Geographies of housing finance: The mortgage market in Milan, Italy. Growth \& Change, 38, 174-199.

Aalbers, M.B. (2008). The financialization of home and the mortgage market crisis. Competition \& Change, 12, 148-166.

Aalbers, M.B. (2013a). Debate on Neoliberalism in and after the Neoliberal Crisis. International Journal of Urban and Regional Research, 37, 1053-1057.

Aalbers, M.B. (2013b). Neoliberalism is Dead... Long Live Neoliberalism!. International Journal of Urban and Regional Research, 37, 1083-1090.

Aalbers, M.B. (2015). The Great Moderation, the Great Excess and the global housing crisis. Journal of Housing Policy, 15, 43-60.

Aalbers, M.B. (2017). The pre-histories of neoliberal urbanism in the United States. In: C. Morel Journel and G. Pinson (Eds), Debating the Neoliberal City. Aldershot: Ashgate.

Allen, J., Barlow, J., Leal, J., Maloutas, T., \& Padovani, L. (2004). Housing \& Welfare in Southern Europe. Oxford: Blackwell.

Ascoli, U., \& Pavolini, E. (2015). Ombre rosse. Il sistema di welfare dopo 20 anni di riforme. Stato e Mercato, 3, 429-464.

Audier, S. (2008). Le Colloque Lippmann, aux Origines du Néo-libéralisme. Lormont: Le Bord de l'Eau.

Audier, S. (2012). Néo-libéralisme(s): Une Archéologie Intellectuelle. Paris: Grasset.

Baldini, M. (2010). La casa degli italiani. Bologna: II Mulino.

Baldini, M. \& Poggio, T. (2014). The Italian housing system and the global financial crisis. Journal of Housing and the Built Environment, 29, 317-334.

Ball, M. (1983). Housing Policy and Economic Power. The Political Economy of Owner Occupation. London \& New York: Methuen.

Bazzoli, N. (2015, December). La Costruzione del Comune nella Città Neoliberista: la Dimensione Costituente della Lotta per la Casa nella Gentrificazione della Bolognina. Paper presented at the workshop "Commons/Comune", Sapienza Università di Roma.

Berdini, P. (2008) La città in vendita: centri storici e mercato senza regole. Rome: Donzelli.

Berdini, P. (2010). Breve storia dell'abuso edilizio in Italia. Rome: Donzelli Editore.

Birch, K., \& Mykhnenko, V. (Eds.) (2010). The rise and fall of neoliberalism. The collapse of an economic order?. London: Zed Books.

Bortolotti, L. (1971a). La proprietà edilizia e il fascismo. Studi storici, 12, 718-778. 
Bortolotti, L. (1971b). La proprietà edilizia e la politica fascista dell'abitazione con special riguardo a Livorno. Florence: Olschki.

Bortolotti, L. (1978). Storia della politica edilizia in Italia: proprietà, imprese edili e lavori pubblici dal primo dopoguerra ad oggi (1919-1970). Rome: Editori Riuniti.

Bottini, F. (2000). Ina-casa: progetto sociale, consenso, idee di spazio. Storia urbana, 90, 99-124.

Brenner, N., \& Theodore, N. (Eds.) (2002). Spaces of Neoliberalism. Urban Restructuring in North America and Western Europe. Oxford: Blackwell.

Brenner, N., Peck, J., \& Theodore, N. (2010). Variegated neoliberalism: geographies, modalities, pathways. Global Networks, 10, 1-41.

Cano, G., \& Etxezarreta, A. (2014). La crisis de los desahucios en España: respuestas institucionales y ciudadanas. Revista de Economía Critica, 17, 44-57.

Cano Fuentes, G., Etxezarreta, A., Dol, K., \& Hoekstra, J. (2013). From Housing Bubble to Repossessions: Spain Compared to Other Western Countries. Housing Studies, 28, 1197-1217.

Carocci, G. (1961). Giolitti e l'età giolittiana. Dall'inizio del secolo alla prima guerra mondiale. Turin: Einaudi.

Castles, F. (1994). On religion and public policy: Does Catholicism make a difference?. European Journal of Political Research, 25, 19-40.

Castles, F., \& Ferrera, M. (1996). Home ownership and the welfare state: is Southern Europe different?. South European Society and Politics, 1, 163-185.

Castronovo, V. (1972). Potere economico e fascismo. Rivista di storia contemporanea, 1, 273-313.

Castronovo, V. (1975). Soggetti pubblici della crescita urbana: gli enti per l'edilizia popolare, 1900-1950. Archivio di studi urbani e regionali, 6, 144-154.

Cave, T. (1999). Pré-histoires: textes troublés au seuil de la modernité. Geneva: Droz.

Chabal, E. (2012). Le néo-libéralisme introuvable ? La Vie des idées, 4 juillet. URL: http://www.laviedesidees.fr/Le-neo-liberalisme-introuvable.html.

Chabod, F. (1962). L'Italia contemporanea (1918-1948). Turin: Einaudi.

Charnock, G., Purcell, T., \& Ribera-Fumaz, R. (2014). The Limits to Capital in Spain. Basingstoke: Palgrave Macmillan.

Colau, A., \& Alemany, A. (2012). Mortgaged Lives. From the housing bubble to the right to housing. Los Angeles. Leipzig and London: Journal of Aesthetics and Protest Press.

Colau, A., \& Alemany, A. (2013). 2007-2012: Retrospectiva sobre desahucios y ejecuciones hipotecarias en España, estadísticas oficiales y indicadores, online report: http://afectadosporlahipoteca.com/wpcontent/uploads/2013/02/RETROSPECTIVA-SOBRE-DESAHUCIOS-Y-EJECUCIONESHIPOTECARIAS-EN-ESPAÑA-COLAUALEMANY1.pdf

Coq-Huelva, D. (2013). Urbanisation and Financialisation in the Context of a Rescaling State: The Case of Spain. Antipode, 45,1213-1231.

De Felice, F. (1969). L'età giolittiana. Studi storici, 10(1), 114-190.

Del Boca, D., \& Lusardi, A. (2003). Credit market constraints and labor market decisions. Labour Economics, 10, 681-703.

Del Pino, E., \& Pavolini, E. (2015). Decentralisation at a time of harsh austerity: multilevel governance and the welfare state in Spain and Italy facing the crisis. European Journal of Social Security, 17, 246-270.

Deriu, F. (2014). II <<Piano Casa>> del Governo Renzi: luci e ombre delle misure sull'emrgenza abitativa. Politiche Sociali, 2/2014, 295-301.

Di Feliciantonio, C. (2016a). Social movements and alternative housing models. Practicing the "politics of possibilities" in Spain, Housing, Theory \& Society, doi: 10.1080/14036096.2016.1220421.

Di Feliciantonio, C. (2016b). Subjectification in times of indebtedness and neoliberal/austerity urbanism, Antipode, 48, 1206-1227.

Doling, J., \& Ronald, R. (2010a). Home ownership and asset-based welfare. Journal of Housing and the Built Environment, 25, 165-173.

Doling, J., \& Ronald, R. (2010b). Property-based welfare and European homeowners: how would housing perform as a pension?. Journal of Housing and the Built Environment, 25, 227-241.

EMF (2009). EMF Hypostat 2008. Report available online: http://www.hypo.org/DocShareNoFrame/docs/3/ABIPMPFBMHACDGAKHCHCJBHNPDWD9DBYTNT E4Q/EMF/Docs/DLS/2010-00176.pdf (retrieved 02/10/2016).

EMF (2015). Key Figures. Brussels: European Mortgage Federation. 
England, K., \& Ward, K. (Eds.) (2007). Neoliberalization: States, Networks, Peoples. Malden: Blackwell.

Fernandez, R., \& Aalbers, M.B. (2016). Financialization and housing: Between globalization and Varieties of Capitalism. Competition and Change, 20, 71-88.

Ferrera, M. (1996). The Southern Model of Welfare in Social Europe. Journal of European Social Policy, 6 , $17-37$.

Ferrera, M. (2012). Verso un welfare più ampio? Conclusioni. In M. Ferrera, V. Fargion and M. Jessoula (Eds.),Alle radici del welfare state allitaliana (pp. 323-343). Venice: Marsilio.

Ficacci, S. (2014). Inquilini a Roma nel Biennio rosso: dale organizzazioni di categoria alle occupazioni delle cose. Storia e Futuro, 34, 1-13.

Ganti, T. (2014). Neoliberalism. Annual Review of Anthropology, 43, 89-104.

Garcia, M. (2010). The Breakdown of the Spanish Urban Growth Model: Social and Territorial Effects of the Global Crisis. International Journal of Urban and Regional Research, 34, 967-980.

García-Lamarca, M. (2016, forthcoming). From occupying plazas to recuperating housing: Insurgent practices in Spain. International Journal of Urban and Regional Research.

García-Lamarca, M., \& Kaika, M. (2016). 'Mortgaged lives': the biopolitics of debt and housing financialisation. Transactions of the Institute of British Geographers, doi: 10.1111/tran.12126.

Genco, B. A. (1929). La proprietà edilizia nei suoi problemi e nella sua organizzazione. Milan: Mondadori.

Gonick, S. (2015a). Indignation and inclusion: Activism, difference, and emergent urban politics in postcrash Madrid. Environment and Planning D. Society and Space, doi:10.1177/0263775815608852.

Gonick, S. (2015b, April). Waking the Civil Dead: Property, Politics, and Resistance in Contemporary Madrid. Paper presented at the Annual Meeting of the Association of American Geographers (AAG), Chicago.

Guillen, A.M., \& Pavolini, E. (2015) Welfare States Under Strain in Southern Europe. Special issue of European Journal of Social Security, 17(2).

Guillen, A.M., \& Petmesidou, M. (2014) Crisis and Austerity in South Europe: Threat or Opportunity for a Sustainable Welfare State?, special issue of South European Society and Politics, 19(3), 295-412.

Guiso, L., \& Jappelli, T. (2002). Private transfers, borrowing constraints, and timing of homeownership. Journal of Money Credit and Banking, 34, 315-339.

Harvey, D. (2009). Is this really the end of neoliberalism? The crisis and the consolidation of class power. Counterpunch, March 13-15. URL: http://www.counterpunch.org/harvey03132009.html.

Hodkinson, S., Watt, P., \& Mooney, G. (2013). Introduction: Neoliberal housing policy- time for a critical reappraisal. Critical Social Policy, 33, 3-16.

Hoekstra, J., Heras, I., \& Etxezarreta, A. (2010). Recent changes in Spanish housing policies: subsidized owner-occupancy dwellings as a new tenure sector?, Journal of Housing and the Building Environment, 25, 125-138.

Hoekstra, J., \& Vakili-Zad, C. (2011). High vacancy rates and rising house prices: the Spanish paradox. Tijdschrift voor Economische en Sociale Geografie. 102, 55-71.

Holland, A., \& Scholar, R. (2009). Introduction. In A. Holland \& R. Scholar (Eds), Pre-histories and Afterlives: Studies in Critical Method for Terence Cave, pp. 1- 14. London: Modern Humanities Research Association and Maney Publishing.

Indovina, F. (2005). Appunti sulla questione abitativa oggi. Archivio di Studi Urbani e Regionali, 82, 15-50.

Jones, D.S. (2012). Masters of the Universe: Hayek, Friedman, and the Birth of Neoliberal Policies. Princeton, NJ: Princeton University Press.

Kemeny, J. (1981). The Myth of Home Ownership. London: Routlegde \& Kegan Paul.

Kitchin, R., O'Callaghan, C., Boyle, M., Gleeson, J., \& Keaveney, K. (2012). Placing neoliberalism: the rise and fall of Ireland's Celtic Tiger. Environment and Planning A, 44, 1302-1326.

Klein, N. (2007). The Shock Doctrine: The Rise of Disaster Capitalism. Toronto: Knopf Canada.

Larner, W. (2000). Neoliberalism: policy, ideology, governmentality. Studies in Political Economy, 63, 5-25.

Lazzarato, M. (2015, eng. transl.). Governing by Debt, trans. Joshua David Jordan. Los Angeles: Semiotext(e) Intervention Series.

Leal, J. (2005). La politica de vivienda en España. Documentación Social, 138, 63-80.

Leibfried, S. (1992). Towards a European welfare state? On integrating poverty regimes into the European Community. In: Z. Ferge \& J.E. Kolberg (Eds.), Social policy in a changing Europe (pp. 245-279). Frankfurt am Main: Campus.

Léon, M., Pavolini, E., \& Guillén, A. (2015). Welfare rescaling in Italy and Spain: political strategies to deal 
with harsh austerity. European Journal of Social Security, 17, 182-201.

Leontidou, L. (1990). The Mediterranean City in Transition: Social Change and Urban Development. Cambridge: Cambridge University Press.

$\mathrm{Li}, \mathrm{T}$. (2007). Practices of assemblage and community forest management. Economy and Society, 36, 263293.

Listokin, D., \& Wyly, E.K. (2000). Making new mortgage markets: case studies of institutions, home buyers, and communities. Housing Policy Debate, 11, 575-644.

Llorden Miñambres, M. (2003). La politica de vivienda del regimen franquista: nacimiento y despegue de los grandes constructores y promotors inmobiliarios de España, 1939-1960. In G. Sanchez Recio \& T. Fernandez (Eds.), Los Empresarios de Franco. Politica y Economia en España (1936-1957) (pp. 145170). Barcelona: Critica.

Lopez, I., \& Rodriguez, E. (2011). The Spanish model. New Left Review, 69, 5-29.

Magagnoli S. (2012). La forma dell'acqua. II Welfare State italiano tra sostegno all'impresa e politiche abitative. In S. Munarin and V. Martelliano (eds.), Spazi, storie e soggetti del welfare. Sul ruolo delle politiche di welfare state nella costruzione della città (pp. 33-48). Rome: Gangemi.

Mingione, E. (1995). Labour Market Segmentation and Informal Work in Southern Europe. European Urban and Regional Studies, 2, 121- 143.

Mirowski, P., \& Plehwe, D. (Eds.) (2009). The Road from Mont Pèlerin: The Making of the Neoliberal Thought Collective. Cambridge: Cambridge University Press.

Mussolini, B. (1928). Cifre e deduzioni. Sfollare le città. II Popolo d'Italia, 22 November.

Newman, J. (2014). Landscapes of antagonism: Local governance, neoliberalism and austerity. Urban Studies, 51, 3290-3305.

Ong, A. (2006). Neoliberalism as Exception. Mutations in Citizenship and Sovereignty. Durham \& London: Duke University Press.

Ong, A. (2007). Neoliberalism as a mobile technology. Transactions of the Institute of British Geographers, $32,3-8$.

Palomera, J. (2014). How Did Finance Capital Infiltrate the World of the Urban Poor? Homeownership and Social Fragmentation in a Spanish Neighborhood. International Journal of Urban and Regional Research, 38, 218-235.

Panitch, L., \& Konings, M. (2009). Myths of neoliberal deregulation. New Left Review, 57(May-June), 67-83.

Pareja Eastaway, M., \& Sanchez Martínez, M. T. (2011). El alquiler: una asignatura pendiente de la Política de Vivienda en España. Ciudad y Territorio. Estudios territoriales, 167, 53-70.

Pareja Eastaway, M., \& San Martin Varo, I. (1999). General Trends in Financing Social Housing in Spain. Urban Studies, 36, 699-714.

Pareja Eastaway, M., \& San Martin Varo, I. (2002). The Tenure Imbalance in Spain: The Need for Social Housing Policy. Urban Studies, 39, 283-295.

Pattillo, M. (2013). Housing: Commodity versus Right. Annual Review of Sociology, 39, 509-531.

Pavolini, E., \& Reitano, M. (2015a). L'Europa mediterranea fra diritti sociali e crisi economica: il welfare state ai tempi dell'austerità. Meridiana, 83, 9-30.

Pavolini, E., \& Reitano, M. (Eds.) (2015b), Welfare mediterraneo, special issue of Meridiana, 83, 9-169.

Pavolini, E., Léon, M., Guillén, A.M., \& Ascoli, U. (2015). From austerity to permanent strain? The EU and welfare state reform in Italy and Spain. Comparative European Politics, 13, 56-76.

Peck, J. (2010). Constructions of Neoliberal Reason. Oxford: Oxford University Press.

Peck, J. (2012). Austerity urbanism: American cities under extreme economy. City: analysis of urban trends, culture, theory, policy, action, 16, 626-655.

Peck, J., Theodore, N., \& Brenner, N. (2010). Postneoliberalism and its malcontents. Antipode, 41, 94-116.

Peck, J., \& Tickell, A. (2002). Neoliberalizing space. Antipode, 34, 380-404.

Poggio, T. (2008) The intergenerational transmission of home ownership and the reproduction of the familialistic welfare regime. In C. Saraceno (Ed.), Families, Ageing and Social Policy. Intergenerational Solidarity in European Welfare States (pp. 59-87). Cheltenham: Edward Elgar Publishing.

Raco, M. (2013). The New Contractualism, the Privatization of the Welfare State, and the Barriers to Open Source Planning. Planning Practice and Research, 28, 45-64.

Regan, S., \& Paxton, W. (2001). Asset-based Welfare: International Experiences. London: IPPR.

Rhodes, M. (1996). Southern European welfare states: identity, problems and prospects for reform. South 
European Society and Politics, 1, 1-22.

Rolnik, R. (2013). Late Neoliberalism: The Financialization of Homeownership and Housing Rights. International Journal of Urban and Regional Research, 37, 1058-1066.

Ronald, R. (2008). The Ideology of Home Ownership: Homeowner Societies and the Role of Housing. Basingstoke: Palgrave Macmillan.

Ronald, R., \& Elsinga, M. (Eds.). (2012). Beyond home ownership: Housing, welfare and society. London: Routledge.

Rose, N. (1999). Powers of freedom. Reframing political thought. Cambridge: Cambridge University Press.

Samona', G. (1973). La casa popolare degli anni 30. Padua: Marsilio Editori.

Springer, S. (2012). Neoliberalising violence: of the exceptional and the exemplary in coalescing moments. Area, 44, 136-143.

Terranova, F. (2011). Dalle case popolari al Social Housing. Successi e miserie delle politiche sociali per la casa in Italia. Techne: Journal of Technology for Architecture and Environment, 1, 36-47.

Tosi, A., \& Cremaschi, M. (2001). Housing policies in Italy. IMPACT Working Paper, The Interdisciplinary Centre for Comparative Research in the Social Sciences (ICCR), Vienna.

Villani, L. (2012). Le borgate del fascismo. Storia urbana, politica e sociale della periferia romana. Milan: Ledizioni.

Vives, S., \& Rullan, O. (2014). The appropriation of real estate income in Soanish neoliberal cities. Boletín de la Asociación de Geógrafos Españoles, 65, 511-514.

Waldron, R. (2016). The "unrevealed casualties" of the Irish mortgage crisis: Analysing the broader impacts of mortgage market financialization. Geoforum, 69, 53-66.

\section{Notes}

${ }^{1}$ EMF data on homeownership rates differ from EU-SILC/Eurostat data reported by the Spanish National Institute of Statistics. According to EU-SILC/Eurostat, the homeownership rate reached its peak in Spain in $2005(80.5 \%)$, while in 2007 it was $80.1 \%$.

${ }^{2}$ The data of the 1921 Census are available online:

http://lipari.istat.it/digibib/censpop1921/Volumell_Regioni/UBO0296435_XIX_Relazione_generale+OCR_otti mizzato.pdf [last visit: 06 June 2016].

${ }^{3}$ In Turin, for instance, from $61.46 \%$ in 1924 to $22.49 \%$ in 1925 (Bortolotti, 1971a).

${ }^{4}$ The data of the 1931 "Special Enquiry on Housing" are available online: http://lipari.istat.it/digibib/Santo/censimento\%20popolazione\%201931\%20NAZIONALI\%20E\%20MONOTEM ATICl/pdf/Indagine\%20speciale\%20sulle\%20abitazioni\%20-\%20Dati\%20riassuntivi.pdf [last visit: 06 June 2016]. Regarding homeownership, the Special Enquiry does not report data on municipalities with a population under 20,000 residents. Because of the war, the census was not realized in 1941 , so there are not available data from the Public Institute of Statistics accounting for the rising of homeownership in the 1930s.

${ }^{5}$ Data available online: http://ucs.interno.gov.it/FILES/AllegatiPag/1263/Pubblicazione_sfratti_2015.pdf [last visit: 06 June 2016].

${ }^{6}$ Cedolare secca is the name of the special tax regime applied for "agreed" private rental contracts. It was instituted in 2011 with two main aims. The first one is contrasting unregistered contracts, while the second is avoiding increases in rents. When created, it was $19 \%$ while the ordinary taxation is $23 \%$ out of the $95 \%$ of rent. 